\title{
Critic on Auguste Comte's Positivism in Sociology (An Islamic Sociology Perspective)
}

\author{
Novita Sari ${ }^{1}$, Jarman Arroisi ${ }^{2}$ \\ Magister AFI UNIDA Gontor ${ }^{1}$, Dosen UNIDA Gontor ${ }^{2}$ \\ novitasarimmq7@gmail.com
}

\begin{abstract}
The rapid science in the modern era, provides significant changes for humans, both in the fields of economics, politics, culture, environment, society, education, and even religion. The 19th century is a century of science that is growing rapidly, this can be seen from the emergence of various scientists who provide concepts, theories based on philosophy with basic ontology, epistemology, and axiology as a contribution to the development of science. One of them, the scientist known as the father of sociology, was Auguste Comte a scientist from France. Comte is famous for its philosophy of postivism because of the many references by scientists in the contemporary era. This is based on the calculation of the success of designing the social structure of modern humans with three stages of law, but one side of the theory he produced has eliminated the fundamental value in humans, namely eliminating the metaphysical basis. In a three-stage law, more concerned with physical values than metaphysical values, this will result in a society that abandons religion and even eliminates the existence of God. The thoughts produced by Comte are thoughts originating from the west, where the basic West is relativism so if viewed from an Islamic point of view this theory will produce atheists and eliminate the sanctity of religion. In Islam religion and society are inseparable because religion is a guideline that is used as a basis in people's lives based on the values of the Qur'an and Sunnah. Therefore in this paper we will study more deeply the criticisms of Aguste Comte's thinking, using qualitative research types, with descriptive analysis methods and theological philosophical approaches.
\end{abstract}

Keywords: Science, Comte

Philosophy as a scientific discipline is the mother of knowledge. In this modern era, philosophy began to be used as a foundation in thinking. In the study of philosophy, everything in the universe that can be reached by empirical-logical can be the object of observation in the development of science. Not only the development of science, more than that, philosophy is also able to be mean in the process of extracting knowledge. One of the example such as produce 
technologies that are proven by natural sciences ${ }^{1}$ and even produce social sciences such as sociology and economics. ${ }^{2}$

In the 18th century, the development of philosophical thought led to the philosophy of epistemology, where philosophical thought is led to the search for truth and reality. ${ }^{3}$ Then, philosophy was influenced by positivism in the 19th century, where truth or reality was measured by its positivistic value. ${ }^{4}$ Positivistic philosophy becomes a balance sheet or benchmark in stating a valid data which only through empirical facts. So, the development of this philosophy has an impact on the metaphysical dimension which is no longer considered important. ${ }^{5}$

However, philosophical thinking is contrary to the principles in Islamic teachings. Islam by its very nature never denies reason as a tool for thinking. In Islam, everything on this earth cannot be separated from belief in Allah as the creator of this nature. What is on this earth is a sign (an unwritten verse) of God's power and greatness which is also aided by the Holy Qur'an (the written verse). Both of these are the benchmarks of truth in Islamic teachings, unlike positivistic. Moreover, removing the metaphysical dimension which is part of the faith of Muslims. Thus, humans can get to know their creator and creature well and think better.

The thought of positivism initiated by Auguste Comte had a very significant influence. Not only the phenomenon of society in which sociology is a science developed from this positivism thinking, but also influences in religious life. Because religious life is closely related to social life. Therefore, this paper

\footnotetext{
${ }^{1}$ Natural science or natural science is a tribe of science whose objects come from natural objects with definite and general laws, which apply at anytime and anywhere. As research in the field of natural knowledge that produces technology such as the use of wave energy and electrical energy so as to produce objects based on technological knowledge such as mobile phones, computers, televisions and others. See, Dani Vardiansyah, Filsafat Ilmu Komunikasi: Suatu Pengantar, (Jakarta: Indeks, 2008), p,11.

${ }^{2}$ F. Budi Hardiman, Pustaka Filsafat Melampaui Positivisme dan Modernitas, "Diskursus Filosofis tentang Metode Ilmiah dan Problem Modernitas”, (Yogyakarta: Kanisius, 2012), 13.

${ }^{3}$ Jumadi, Perkembangan Filsafat Abad Modern, (Yogyakarta: Universitas Negeri Yogyakarta, 2017), p,2.

${ }^{4}$ Mohammad Muslih, Filsafat Ilmu (Kajian Atas Asumsi Dasar, Paradigma dan Kerangka Teori Ilmu Pengetahuan), (Solo: LESFI, 2016), p,88.

${ }^{5}$ Koento Wibisono Siswomihardjo, Arti Perkembangan Menurut Filsafat Positivisme Auguste Comte, (Yogyakarta: Gadjah Mada University Press, 1996),p, xiii.
} 
will criticize Auguste Comte's positivism especially in the social sphere from an Islamic perspective.

\section{METHOD}

This research is a qualitative study whose data is not obtained through quantitative procedures, statistical calculations, or other forms of numerical use. This research also includes library research. This is because the studies and analyzes in this research are sourced from libraries such as books, journals, articles, magazines, and other library resources that are hardfile or softfile. The method used in this paper is descriptive analysis which is a method based on a description of what comes from a place or figure of an actor, and processes, organizes, groups data, looks for patterns or themes, with a view to understanding their meaning. While the analysis technique uses a philosophical and theological approach. The philosophical approach is the freedom of human thought towards all things without limits, referring to the law of doubt on all respects and means a human effort to understand the passion of faith or his religious passion, an interpretation of its sources and traditions in the context of today's problems.

\section{RESULTS}

Auguste Comte's positivism contained several things that were contrary to Islamic teachings. Where it makes Muslims cannot apply the philosophy of Auguste Comte in life, including in sociology. These include positivism which rejects metaphysics. In Islam, metaphysics is related to belief. Because believing that the unseen is one of the faith in Islam. A person does not believe if he does not believe in the existence of the unseen.

Furthermore, it relates to the law of three stages. Where this law is the development of human thought that has been drafted by Auguste Comte. Starting from theology, it developed into a metaphysical and ended in positive. Comte seeks to abolish theology and metaphysics, so that modern humans only think positively. Of course this is contrary to the teachings of Islam, just as before. This 
abolition actually aims to separate the relationship between science and religion. Which of these three-stage legal concept is also applied in sociology.

\section{DISCUSSION}

The scientific mindset based on the natural philosophical mindset is automatically applied in seeing the social phenomena. Observation of natural methods applied in social phenomena called social science (sociology). ${ }^{6}$ Most of the concepts and methods used in sociology come from the theory of philosophy of positivism. ${ }^{7}$ Not only in social science, the philosophy of positivism also has an influence in living the life process in society. This is indicated by the flow of ethical philosophy in the study of philosophy called moral philosophy. This moral philosophy aims to make the scientific facts that exist in the community as a measure of community life.

Tracing the thought in seeing social practices, certainly in the discipline of sociology that the application of the philosophy of positivism has a great influence to answer the social problems. Comte as the father of sociology states that the ideas conveyed are scientific. And divide it into two categories, namely social statics and social dynamics. Social statics is a social law that regulates the interconnection between institutions and different forms of culture. This social statics is a branch of the science of sociology that is devoted to establishing a law of similarity that regulates the actions and reactions of parts of the social system between one and another that are permanent. Social dynamics are also a special discussion in studying the changes and developments in history from one form to another. ${ }^{8}$ One of the greatest laws is historical continuity. In this regard, Comte has explained three stages of the development of human thought namely the theological, metaphysical and positive stages. In social life the social order is a natural condition formed by the community. With this natural condition, Comte

\footnotetext{
${ }^{6}$ Mohammad Muslih, Filsafat Ilmu, p,11-12.

${ }^{7}$ Jumadi, Perkembangan Filsafat Abad Modern, p, 74.

${ }^{8}$ M. Sanusi, "Telaah Epistemologi Positivisme dan Fenomenologi (Sebuah Perbandingan)", dalam Jurnal Asketik, Vol. 2, No. 1, Juli 2018,p, 66.
} 
believes that with a positive approach, harmony in society can be maintained or disciplined.

The law of three stages or also called evolutionary theory tends to see the social change as a linear process. That is, social societies develop following the same developments starting from theological, to metaphysical and to positive. ${ }^{9}$ In this theory, Comte focuses its attention on intellectual factors. He said that intellectuals caused social chaos originating from a system of previous ideas (theology and metaphysics) which still continue to exist in a positive (scientific) era. According to him, new social groups will emerge if people's lives are fully controlled by positivism, although not as quickly as expected. At each stage, Comte says there will always be a consensus that leads to social order. The order referred to is the existence of an agreement of shared views and beliefs. ${ }^{10}$

In sociology, there are other characteristics that emerge from these three stages. At the theological stage, the family is the dominant social unit. At the metaphysical stage, the power of the nation-state that gives rise to a sense of nationalism or nationality becomes a dominant organization. When at the positivistic stage, social order arises which is marked by the emergence of industrial societies that are concerned with the human side. Here Comte explains, at this stage a humanity religion will emerge, which then the sociologist will become the priest of a new religion that will guide humans in a harmonious life. Sociologists will teach humans to think positively-scientifically and connect the doctrines of love, order and progress with human life. This humanity religion is expected to guarantee a social order in a positive society. ${ }^{11}$

Thus, the application of positivistic values in sociology can provide an important role for studies in society. This important role can be used to shape and develop a society through its various techniques and methods. ${ }^{12}$ In other words,

\footnotetext{
${ }^{9}$ Herabudin, Pengantar Sosiologi, (Bandung: Pustaka Setia, 2015), p, 255.

10 Nanang Martono, Sosiologi Perubahan Sosial, (Jakarta: PT Raja Grafindo Persada, 2014),p, 42.

${ }_{11}$ Nanang Martono, Sosiologi Perubahan Sosial,p, 42.

12 Galeh Prabowo, "Positivisme dan Strukturalisme: Sebuah Perbandingan Epistemologi dalam Ilmu Sosial”, dalam Jurnal Sosiologi, Walisongo, Vol. 1, No. 1, 2017, p,35.
} 
sociology is able to be an instrument in various government policies in an effort to analyze and evaluate various problems in society, as well as being used for the purpose of empowering the community for the achievement of all matters related to the development process.

On the one hand, this positivism of sociology is seen as a solution to social life. However, in essence, he violated several main principles in the teachings of religion, especially Islam. If examined further, positivism which is applied in sociology is only a theory that is considered perfect but is not applicable and can be used universally. Therefore, Islam actually has its own concept of sociology which is more universal than Comte's.

While positivism in Islamic studies is present because of the approaches to Islamic studies are more likely to be subjective, apological, and doctrinal. This approach is also said to be closed to the approach taken by outsiders (nonMuslims or Orientalists) that are objective and rational. With this subjective approach, apology and doctrinaire, the teachings of Islam originating from the Qur'an and Hadith have become normative, rigid and taboo teachings of rational touches, demands for change, and the development of the times. In fact, the life, religion and culture of Muslims seem stagnant, frozen and out of date. ${ }^{13}$ Therefore, all kinds of scholarship have an impact on the thesis so that scientists try to separate the relationship between science and religion.

In positivism, a positive value is a reference in determining science. Where the senses are a tool used as reading the reality that occurs in society. However, it must be realized that the five senses are gifts from God that are extraordinary and their roles must be maximized. Even with the senses humans are able to get to the knowledge of their Lord. ${ }^{14}$ Therefore, the separation between science and religion cannot actually be applied, because the five senses cannot be separated from reality.

${ }^{13}$ Abuddin Nata, Metodologi Studi Islam, (Jakarta: Rajawali Press, 2013),p, 154.

14 Mohammad Muslih, Rekonstruksi Nalar Keagamaan; Ikhtiar Menemukan Konteks Agama bagi Pengembangan Sains, dalam Jurnal Afkaruna, Vol. 14, No. 2, Desember 2018, p,194. 
A positivistic scientific approach cannot actually be used in Islamic studies. Because basically, positivism rejects metaphysical matters, whereas metaphysics in Islam is a must to believe. In addition, empiricism which is also an absolute thing in positivism will certainly collide because the Islamic religion does not always have its empirical aspects. If positivism is applied, it will have implications for Islamic thought and its sciences. Islamic sciences that exist and develop to date include interpretations of the Qur'an (tafsir), the explanation of Hadith (syarah), fiqh, kalam, Sufism, and Islamic politics.

Between the implications of the theory of positivism on the tafsir of Qur'an is that interpretation cannot be considered a definite science. The nature of positivism requires that science is certain and the relative truth. With reason, the interpretation that came later, cannot erase the previous interpretation. So that the commentators who have different interpretations of the verses of the Qur'an, cannot be considered as objective science. When the syarah Hadith is also almost the same as faced by the tafsir. Syarah Hadith develops in accordance with internal and external influences in the explanatory of the Hadith. Syarah that comes lately also cannot be erase by the previous syarah. So this knowledge is also considered as knowledge that is not objective, certain, true, and positive.

Furthermore, the implications for fiqh. In its development, fiqh is divided into four schools which are also considered not positive. According to positivism, fiqh that develops should be an absolute, certain, and correct school of thought, not fragmented into four. Implications for kalam also, its development gave rise to many Islamic groups and groups. At first, the kalam flow as if trying to erase the previous kalam flow. In fact, an understanding cannot be erased as long as there is someone who knows and considers that the flow which he professes is the most correct flow. Positivism cannot accept this, so this theory requires understanding a single kalam school only.

The implications for Sufism are the same as the previous discussion. Sufism also has many streams, so the theory of positivism does not consider Sufism as a true science, because it still has a lot of understanding in it. When the 
implications for Islamic politics too, developing politics also has many streams, such as Sunni and Shia. In Indonesia, Islamic politics in Indonesia is divided into camps, such as Nahdhatul Ulama and Muhammadiyah. So this is not justified by Comte's positivism, because if science is true, then there is only one that should be held by all Muslims. ${ }^{15}$

From these implications, it can be seen that positivism does not accept differences. Adherents of positivism still insist that there is only one truth. Whereas in Islam, that difference is a blessing. In a sense, the difference is only in things that are justified furuiyah, not things that are in ushul. And it must be known that there are various conditions agreed upon by the ulama or scholars to have an opinion or ijtihad. So not all Muslims, from any level and academic degree may emigrate in the name of scientific freedom. ${ }^{16}$

Then, positivism developed through the law of three stages as the development of human thought which is the basic reference for the emergence of this flow. This three-stage law is also used in the development of scientific disciplines including sociology. This three-stage law is incompatible with what Islam teaches. To achieve positivity, it is not necessary to eliminate theological and metaphysical aspects. Just as before, that this law seeks to separate the relationship between religions who believe in a god who is metaphysical and positive only who rely on reason and thought alone. Through this basis, the sociology of Auguste Comte was indirectly rejected in an Islamic perspective.

In fact, Islam already has its own concept of sociology. In contrast to what is offered by Auguste Comte and other Western scientists. For Muslims, Islam is an ideology that determines the totality of Muslim life. Where Muslims must develop all their behavior, including social behavior, based on the values of faith. It must be admitted that Rasulullah saw. is the world's best figure who has exemplified how to behave in social life. The social process undertaken by the

${ }^{15}$ Abdullah Saed, Islamic Thought: An Introduction, (New York: Routledge, 2006), p,viiiix.

${ }^{16}$ Suryan A. Jamarah, "Iktilaf dan Etika Perbedaan dalam Islam”, dalam Jurnal Toleransi: Media Komunikasi Umat Beragama, Vol. 6, No. 2, Juli-Desember 2014, p,226. 
Prophet begins with the guidance of "iqra". Then enter the arena community to lead social movements through the guidance of "al-muddatstsir". After the development and formation of the Islamic community began to show a better form among the Arabs regionally, The Prophet entered into international relations by offering Islam as a way of life. ${ }^{17}$

Many scientists are more oriented towards the West than Islam because they think Islam is not a "human center". In fact, the Qur'an is revealed by placing humans at the center of their interests, where other beings are positioned to serve humans. ${ }^{18}$ Like animals and plants as human food. Angels are assigned to take care of humans. Including the devil who always tried to plunge humans into digression. The sign of Allah's compassion is to bring down the Qur'an as a guide for all people ${ }^{19}$ in the right direction. ${ }^{20}$

For the good of human life, the Qur'an emphasizes two main things, namely the relationship with God (habblu min Allah) and the relationship with fellow human beings (habblu min an-nas). ${ }^{21}$ The two main points are sociological aspects that are very central and important. Without these two relations being established properly, human life is threatened with misery and contempt. Most of the verses of the Qur'an are oriented to the actualization of these two relations. This is because the relationship to God also affects the relationship between humans. In fact, rituals such as prayer, fasting, almsgiving and others are also related to relations with each other. ${ }^{22}$

In a Hadith qudsi narrated by Imam Baihaqi, the Prophet Muhammad (pbuh) said;

"Allah will only accept prayers from people who humble themselves before My majesty, are not arrogant towards my fellow creatures,

${ }^{17}$ Aam Abdussalam, "Teori Sosiologi Islam (Kajian Sosiologis terhadap Konsep-konsep Sosiologi dalam Al-Qur'an Al-Karim)", dalam Jurnal Pendidikan Agama Islam - Ta'lim, Vol, 12, No. 1, 2014, p,25-26.

${ }^{18}$ QS. Al-Baqarah 2:29.

${ }^{19}$ QS. Al-Baqarah 2:185.

${ }^{20}$ QS. Al-Isra' 17:9.

${ }^{21}$ QS. Ali Imran 3:112.

${ }^{22}$ Aam Abdussalam, "Teori Sosiologi Islam (Kajian Sosiologis terhadap Konsep-konsep Sosiologi dalam Al-Qur'an Al-Karim)", p,26-27. 
spend the day remembrance of Me, do not intentionally commit sins at night, like to feed the hungry, give protection to those who are troubled, love the small, and respect the big ..."

The concept of hablu min Allah and habblu min an-nas are an inseparable unity. That is, one's social interaction is not neutral from divine values. When someone realizes his social relations with others, in essence he is actualizing a relationship with his Lord. Thus, the sociology of Auguste Comte's positivism which eliminates aspects of theology and metaphysics is very contrary to the concept of Islam and cannot be used by Muslims.

\section{CONCLUSION}

From the discussion above, in the aspect of sociology in particular, the sociology that Auguste Comte built was very influential with his positivist philosophy. Because he himself has a goal to build a positive society. From the foregoing discussion, sociological positivism is not appropriate in the lives of Muslims. Therefore, sociology that is in accordance with Muslim life is Islamic sociology. Where the main theories of Islamic sociology are habblu min Allah and habblu min an-nas. Which means, there is no separation of relations between God and humans. Because in truth, the relationship to God is the actualization of relationships between human beings. 


\section{BIBLIOGRAPHY}

Abdullah Saed, (2006). Islamic Thought: An Introduction, New York: Routledge. Abdussalam, Aam, “Teori Sosiologi Islam (Kajian Sosiologis terhadap Konsepkonsep Sosiologi dalam Al-Qur'an Al-Karim)”, dalam Jurnal Pendidikan Agama Islam - Ta'lim, Vol, 12, No. 1, 2014

Hardiman, F. Budi. (2012). Pustaka Filsafat Melampaui Positivisme dan Modernitas, "Diskursus Filosofis tentang Metode Ilmiah dan Problem Modernitas”, Yogyakarta: Kanisius.

Herabudin, (2015). Pengantar Sosiologi, Bandung: Pustaka Setia.

Jamarah, Suryan A. "Iktilaf dan Etika Perbedaan dalam Islam", dalam Jurnal Toleransi: Media Komunikasi Umat Beragama, Vol. 6, No. 2, JuliDesember 2014.

Jumadi, Perkembangan Filsafat Abad Modern, (Yogyakarta: Universitas Negeri Yogyakarta, 2017), p,2.

Martono, Nanang. 2014. Sosiologi Perubahan Sosial, Jakarta: PT Raja Grafindo Persada.

Muslih, Mohammad Rekonstruksi Nalar Keagamaan; Ikhtiar Menemukan Konteks Agama bagi Pengembangan Sains, dalam Jurnal Afkaruna, Vol. 14, No. 2, Desember 2018, p,194. (2016). Filsafat Ilmu (Kajian Atas Asumsi Dasar, Paradigma dan Kerangka Teori Ilmu Pengetahuan), Solo: LESFI.

Nata, Abuddin. (2013). Metodologi Studi Islam, Jakarta: Rajawali Press.

Prabowo, Galeh "Positivisme dan Strukturalisme: Sebuah Perbandingan Epistemologi dalam Ilmu Sosial”, dalam Jurnal Sosiologi, Walisongo, Vol. 1, No. 1, 2017

Sanusi, M. "Telaah Epistemologi Positivisme dan Fenomenologi (Sebuah Perbandingan)", dalam Jurnal Asketik, Vol. 2, No. 1, Juli 2018

Siswomihardjo, Koento Wibisono.(1996). Arti Perkembangan Menurut Filsafat Positivisme Auguste Comte, Yogyakarta: Gadjah Mada University Press Vardiansyah, Dani. (2008). Filsafat Ilmu Komunikasi: Suatu Pengantar, Jakarta: Indeks. 